The Globalization of MANAGEMENT

CONSULTANCY FIRMS: CONSTRAINTS AND

LIMITATIONS

Glenn Morgan, Andrew Sturdy and Sigrid Quack

CSGR Working Paper No 168/05

May 2006 


\section{The Globalization of Management Consultancy Firms: Constraints and Limitations}

Glenn Morgan, Andrew Sturdy and Sigrid Quack

CSGR Working Paper No 168/05

May 2006

\section{Introduction}

This paper is aimed at providing a framework for the analysis of organizational structures and processes in the global management consulting industry. Our basic question is why do global consulting firms exist? What distinctive advantages (if any) are they able to bring to their clients and the consulting task which cannot be achieved by 'national' firms? Consideration of this question leads us into alternative modes of internationalisation in this sector. Economists in the field of international business have long posed this question in relation to manufacturing firms (e.g. Dunning 1993). However, their answers tend to be limited to economic considerations and ignore the ways in which issues of organizational structure, power and processes impact on the internationalising strategies of firms. More recently other authors have posed the same question specifically in relation to professional services firms (Aharonhi 2000: Lowendahl 2000; Nachum 2000; Roberts 1998; 1999; 2004). These authors have argued that there are specific characteristics of professional services that require an adaptation of the dominant models of internationalisation. These relate to the distinctive interface between clients and suppliers in these contexts where co-presence and interaction is typically essential. This interaction in conditions where knowledge is ambiguous and/or clients may be less 'knowledgeable' than the professionals about the nature and quality of the services delivered has tended also to lead to national regulatory regimes controlling how some professional services are delivered, monitored and controlled. These factors have tended to militate against the 
globalization of professional services. However, in recent years, the development of professional services outside strong regulatory frameworks of practice (such as in the case of management consultancies and advertising agencies), the gradual decline of national regulatory regimes under pressures of 'free trade' and the increased international standardisation of certain forms of professional services (such as audits) has opened up more possibilities for the internationalisation of firms in this area. The general phenomenon of what Giddens (1990) has labelled 'time-space distanciation' in theory makes it easier to both maintain communication and control across widely spread national contexts and also to facilitate forms of cross-national team-building and cooperation. For all these reasons, the services sector in general and professional services in particular has seen a massive expansion of international activity over the last two decades. Bryson et al, for example state that 'the value of world commercial services exports has increased some 3.5 times between 1980 and 1999’ (Bryson et al. 2004: 217). The 2004 World Investment Report from UNCTAD noted that 'on average, services accounted for two-thirds of total FDI inflows during 2001-2, valued at some \$500 billion’ (UNCTAD 2004: xx). Interestingly, the report went on to state that 'as the transnationalization of the services sector in home and host countries lags behind that of manufacturing, there is scope for a further shift towards services' (ibid.). This suggests that the organizational issues concerned with the internationalization of service firms have not disappeared. It is these organizational issues which lie at the heart of our concerns.

In order to assess these organizational issues, we refer to the emerging literature which goes beyond the issue of the economic advantages of internationalisation to MNCs towards considering how organizations can manage the complex inter- 
relationships between the different parts of multinationals (Morgan et al. 2001; Geppert et al. 2003; Kristensen and Zeitlin 2005; Whitley 2005). What organizational forms enable multinationals to achieve these proposed advantages and what are the limitations to this process? Most of this discussion has taken place in the context of manufacturing industry (c.f. Morgan and Quack 2005) and part of our objective is to show how a similar analysis can be made relevant particularly for management consultancy firms.

The paper consists of the following sections. Firstly, we begin by discussing the general issue of why do global firms per se exist? This literature is predominantly driven by an understanding of manufacturing firms rather than services. This is useful in that it begins to make clear both what the main problems are with regard to the organization and coordination of global firms and how these might relate to other organizational forms. The second part of the paper examines these debates in relation to professional services firms with a particular focus on the types of internationalisation available to services companies and the factors which influence particular strategies. This section explores in particular the specific characteristics of professional services and the way in which this impacts on internationalisation. As with manufacturing, professional services can, in theory, be delivered across national borders in a variety of ways ranging from exports through to the establishment of affiliates in other countries. However, most analysts recognise that services, particularly those professional services such as management consultancy with which this chapter is concerned, require a level of face-to-face interaction with clients that is not the case in manufacturing. The importance in professional services of what is often referred to as the simultaneity of production and consumption which leads to the 
non-tradability (across borders) of many services therefore tends to militate against export strategies and in principle to favour the establishment of subsidiaries or affiliates in particular localities. This is, of course, complicated by many other factors, such as national regulations, cultural differences and established client relationships which have in the past acted as barriers to the establishment of subsidiary affiliates. However, in the last two decades, an increasing number of professional service sectors (including management consultancy) have seen the emergence of 'global firms' with strategies based on the expansion of local affiliates in multiple jurisdictions. We examine some of the issues which arise from this expansion. In the third section, we focus more specifically on the management consultancy industry. This industry contains a number of 'global' companies with affiliates in many different countries. What we are particularly interested in is the way in which they work organizationally and how their structure as a global firm is reflected in their practices. We present a broadly sceptical account of the globalization of their practices. We argue that there is a disjuncture between the 'global' image and the 'local’ reality. This in turn raises two important areas of debate. Firstly why does this disjuncture exist and how is it reproduced? Secondly what does this mean for the market for management consultancy services in any particular country?

Taking a range of indicators, we argue that there are substantial organizational barriers to achieving the economies of scale, scope and learning predicted by economic accounts of these firms. We argue that there are high costs entailed in sustaining the global firm model in consultancy whilst the benefits are uncertain. The reason they are sustained, therefore, is more to do with the effect of reputational and legitimacy considerations and these firms' abilities to convince their clients and others 
of their efficacy. In particular, the ambiguity and uncertainty of managerial action in general and of the impact of management consultants on firms leads to proxy indicators of their effectiveness (Clark, 1995). These proxy indicators frequently include the characteristics of the firms themselves in relation to factors such as size and global reach, the elite status of recruits and the influential networks into which global consultancies are connected. Thus the global consulting firm with high reputation and high legitimacy to other global actors (most obviously institutional investors and shareholders) becomes a preferred partner in a variety of contexts because its 'potency' rubs off on its client, whatever happens at the level of any particular consultancy project. Similarly, the client's status and reputation can work back on reinforcing that of the consultancy (e.g. with 'blue chip' clients). However, because of the costs of such services (related, inter alia, to the high costs of coordination in such firms) and the nature of many of them, these firms by no means sweep the board. Their services are basically directed to a particular group of large international firms ${ }^{1}$ and large scale projects such as outsourcing. This implies that beneath this level, there will be opportunities for many other forms of management consulting organization, not just in local settings but also across national borders. Here the specificity of national institutional contexts as an influence on the demand for management consultancy services remains especially strong. We therefore need to be cautious about analysing the management consultancy industry purely from the point of view of the large global firms. The survival and development of small firms locally, nationally and internationally modifies this picture substantially.

\footnotetext{
${ }^{1}$ We should also note here the increasingly important role these global consultancies play in advising governments, transnational bodies and large scale voluntary international organizations on a range of issues.
} 


\section{Global firms: the lessons from manufacturing}

The internationalisation of manufacturing firms has been intensively studied. This reflects the economic and social context of the period from the 1950s through to the 1980s when it was the export of manufactured goods and the growth of foreign direct investment to fund production facilities overseas that characterised the increasing internationalisation of the world economy. In this process, the 'multinational firm' became increasingly prominent as the organizational form which was central to internationalisation. Dunning's 'eclectic theory' of the multinational explained its emergence in terms of the interaction between ownership advantages, location advantages and internalization advantages (Dunning 1993). Thus firms which had developed effective and efficient forms of production in their home context would seek to leverage their existing economies of scale and scope (ownership advantages) by expanding into new locations. Locations would be chosen according to their own advantages such as enabling the firm to avoid tariff barriers, be close to markets and consumers, reduce costs (of transport, raw materials and in some cases, labour) and enable access to new sources of capital and knowledge (location advantages). Such decisions would also be influenced by the costs and benefits of internalisation of this process, as opposed to following alternative strategies such as export, licensing and franchising (internalisation advantages).

During the late 1980s and 1990s, these arguments became more complex as theories of the multinational shifted away from the heavily centralised view which characterised earlier discussions towards views of the MNC as a 'heterarchy' (Hedlund 1986; 1993; 1999) or ‘differentiated network’ (Nohria and Ghoshal 1997). In this view, the efficiency of the MNC derived not just from its ability to leverage 
economies of scale and scope but also from its access to multiple sites of expertise and learning which increased its capacity for innovation. In Bartlett and Ghoshal's model (1989) of the 'transnational firm', flows of information and knowledge across different sites within the MNC via various forms of information gathering, organizational structuring and project team work gave the MNC distinctive new capacities for innovation that could not be matched inside nationally based firms. Thus in organizational terms, the problem was how to develop a structure, strategy and management system that would enable the successful achievement of this process of learning and the emergence of the 'transnational firm'. Bartlett and Ghoshal emphasize that this is not an issue of structure. The transnational cannot be reduced to a structural model along the lines of a matrix where the tensions between the three core objectives are mediated through formal reporting relationships. Responsibilities for decisions in the transnational will tend to gravitate to the most appropriate level in the organization. They state that transnationals 'decide task by task and even decision by decision where issues should be managed. Some decisions will tend to be made on a global basis, often at the corporate centre...; others will be the appropriate responsibility of local management. But for some issues, multiple perspectives are important and shared responsibility is necessary’ (Bartlett and Ghoshal 1989: 209). In many ways it is the task of the headquarters to balance between different focuses and change these frequently. A hierarchical structure cannot be imposed on this diversity which is more like a 'differentiated and interdependent network....integrated with a flexible coordinating mechanism' (ibid: 210). In Hedlund's terminology, the firm moves from hierarchy to heterarchy. 
This model in turn has raised three interesting debates which we will return to through the rest of this chapter (for an overview of these debates see Morgan 2005). The first which we label 'the subsidiary autonomy' debate concerns the nature of subsidiaries and the knowledge and skills embedded in subsidiaries. In the earlier model of the MNC, subsidiaries were generally presented as 'passive'; they were recipients of the knowledge and skills transferred from the home base. In the emerging model, however, subsidiaries are perceived as 'active' with their own socially embedded skills and knowledge (Birkinshaw, 1997; 2000; 2001). More recent analysis has linked this in particular to institutional arguments in which subsidiaries may have their own distinctive sets of competences and capabilities which arise from their particular local institutional context, e.g. in terms of the skill profile of their employees or the nature of the cooperation between employees and managers which exists in a particular context with consequent effects on product innovation and process improvement (Belanger et al. 1999; Kristensen and Zeitlin 2005). From this perspective local sites are arenas of negotiation and adaptation between locally embedded actors and procedures, practices, technologies and personnel drawn from head office. Within the MNC, local sites range in the degree of autonomy and control which they construct for themselves in the internal processes of the wider firm. Some subsidiaries become active players in the construction of the firm, its boundaries, its strategies and structures whilst others are more passive.

The second debate concerns how these subsidiaries develop their distinctive capacities and capabilities and how these are coordinated across the multinational - we label this the MNC governance debate. As subsidiaries are (to varying degrees) connected into local networks of firms and institutions, it is the capacities of this local context that 
provide the distinctive capabilities of the subsidiary within the MNC. Solvell and Zander (1998) refer to how subsidiaries tend over time to deepen their attachment to the local context and loosen their connection to the MNC as a whole (see also Solvell 2003). Kristensen and Zeitlin (2005) identify similar aspects in their study of a particular MNC. This demonstrates that the local subsidiaries of the MNC have their own distinctive characteristics in terms of relations between managers, employees and surrounding networks of firms and local government institutions. These distinctive characteristics influence their abilities to participate in the competitive internal market. Their study raises the issue of how head office managers are able to reap the benefits of this by, on the one hand, sustaining local innovative networks and on the other hand developing mechanisms which transfer some of the skills and knowledges around the MNC itself. How is it possible to move this knowledge around effectively? How is it possible to sustain local networks whilst ensuring that there are economies of scale, e.g. from global supply management? Kristensen and Zeitlin argue that the current form of governance in most multinationals militates against this form of cooperation, instead setting sites against each other in a zero sum game. Therefore a central question for the MNC, in common with large firms generally, is how to manage and govern relations between the various constituent parts.

The third debate touches on this by bringing back in the issue of coordination costs. Can global firms do this better than markets or, more likely, inter-firm networks of various types? We label this the 'coordination costs' debate. A number of recent authors have pointed to the decline of the large integrated 'Chandlerian' firm. Langlois, for example, has argued that 'rather than seeing the continued dominance of multi-unit firms in which managerial control spans a large number of vertical stages, 
we are seeing a dramatic increase in vertical specialization....In this respect, the visible hand - understood as managerial coordination of multiple stages of production within a corporate framework - is fading into a ghostly translucence' (Langlois 2003: 352; see also Lamoreaux et al 2002; Sturgeon 2002). Langlois describes what he terms the emergence of 'a richer mix of organizational forms' in the 'new economy' arising from vertical disintegration and specialization. These forms relate to modes of coordination between different types of firms. One broad label for this whole process is, of course, Castell's 'network society’ (1996) and this does indeed reflect Langlois’ earlier interests in the relationship between markets, hierarchies and networks (Langlois and Robertson 1995). In the network model, firms specialise in particular positions in the value chain. So long as firms at different points can create mechanisms which allow cooperation and communication across boundaries, the network model reduces coordination and transaction costs whilst enhancing innovative capacities. More generally, higher levels of flexibility can be achieved through firms linking to others as and when needed rather than incorporating a wide range of skills inside the firm itself. The same argument can be applied to MNCs. In Kristensen and Zeitlin's analysis, the economic value added by the head office is problematic. The internal conflicts which are set in train by the competition for investment and mandates generates high amounts of effort and cost that may be economically unviable in the long run as the only way to control them is to increase standardisation and this in effect undermines the raison d'etre of the MNC as it destroys local variety and diversity, thus weakening the capacity for innovation.

These arguments point to the need to be critical and analytical about the emergence of global firms. As such firms try to access all the advantages which Dunning describes, 
their managerial problems increase because the maintenance of hierarchical control is difficult and counter-productive, whilst the development of heterarchical controls makes the whole system more difficult to govern in a consistent and coherent manner. It is not at all clear how these problems of governance can be resolved in ways that do not simultaneously undermine what are perceived as the main advantages of the MNC. This suggests the importance of firstly being sceptical of the claims which are made for the economic efficiency of the MNC and secondly being open to the emergence of different forms of coordination across national boundaries. Such a perspective has not yet been applied to the internationalisation of the service sector. In the next section, we consider the dominant interpretations of internationalisation amongst service firms before going on to provide our own account building on this distinctive view of multinationals.

\section{Internationalisation and the Service Sector}

Recent decades have seen an increased interest in the internationalisation of the service sector. The recent UNCTAD World Investment Report 2004 was entitled 'The shift towards services'. The report indicates that $60 \%$ of the world's FDI stock was in this sector in 2002 (up from 25\% in the early 1970s). Measuring internationalisation more broadly than simply through FDI in the service sector has been problematic. The UN as part of its attempt to measure this phenomenon has recently classified services trade into the following categories:

“Mode 1, cross border supply occurs when suppliers of services in one country supply services to consumers in another country without either supplier or consumer moving into the territory of the other. 
Mode 2, consumption abroad refers to the process by which a consumer resident in one country moves to another country to obtain a service.

Mode 3, commercial presence occurs when enterprises in an economy may supply services internationally through the activities of their foreign affiliates

Mode 4, presence of natural persons describes the process by which an individual moves to the country of the consumer in order to provide a service, whether on his or her own behalf or on behalf of his or her employer.” (UN 2002 Manual on Statistics on International Trade in Services quoted in Bryson et al. 2004: 200)

Generally the main interest in the internationalisation of services refers to mode 3, the expansion of what we refer to as 'global firms' in professional services. By global firms, we mean firms that have significant affiliates or branch offices outside their home state ${ }^{2}$. In the professional services environment, the establishment of these global firms has occurred at different rates in different sectors. Thus by the 1990s, the firms which now make up the Big Four ${ }^{3}$ global accountancy firms had offices in most countries in the world. In the law sector, however, globalisation processes have been much slower and even now what are termed global law firms tend to have a small number of offices located in around 10 key centres (or 'global cities' in Sassen’s term Sassen 2001: Taylor 2004) rather than being spread across the globe. Furthermore, it is only in the last few years that mergers of law firms across distinctive national systems have occurred as opposed to the opening up of new branch offices (Beaverstock et al. 1999; 2000; Beaverstock 2004; Morgan and Quack 2004; Spar 1997; Warf 1997). Even then merger processes are slow and constrained occurring

\footnotetext{
${ }^{2}$ In this context, we are not so concerned with the degree of globalization per se or with whether these firms are best described as 'regional multinationals' rather than global firms (see Morgan and Quack 2004 for a more nuanced discussion of this in relation to law firms).

${ }^{3}$ By the time of the collapse of Andersens, the big accountancy firms were four in number reducing from the Big Six in the early 1990s and the Big Five in the late 1990s.
} 
mostly across a small number of jurisdictions (e.g. the US and the UK, the US/UK and Germany).

Dunning (1993) identifies a range of factors within his eclectic OLI model that particularly influence this process in service firms. Under the category of ownership advantages, he notes the importance of quality consistency, reputation and product differentiation to keeping and winning clients in overseas location. In terms of location, the two crucial issues are whether the service is tradable and whether the regulatory framework is open. If the service is non-tradable across borders and requires co-presence, then the service firm has to locate in order to win business, even where it has an existing long-standing relationship with the client but in different national contexts. However, this requires that there are no regulatory barriers to foreign presence, which was not the case in many professional services until recently. Finally where the service requires customization and interaction with the client, it cannot really be delivered by franchise or licensing. The firm has to retain the skills in-house and to deliver them to clients itself. Under these circumstances, Dunning predicts the emergence of international professional service firms.

Other authors have linked ownership and internalization advantages to the issues of knowledge and learning in two ways, firstly that of leverage and secondly that of innovation. Leverage implies that resources established in one context can be re-used in other contexts. The degree to which professional services fit this is variable depending on the types of business. For example, at first sight, a law firm in London has no obvious resources which would enable it to compete effectively in Shanghai. However, things are rarely as simple as much commercial business between 
multinationals in Shanghai and the law associated with it is likely to be based on English law. Therefore the more accurate analysis would be that the UK law firm has no advantages to bring to a situation where it is competing for local clients but it has many where it is working for UK MNCs or other firms that are having to contract under English law. Furthermore, once established it may be able to compete for local business on the grounds of its international reputation (assuming it has employed local lawyers in its office).

The issue of reputation is crucial in this context. As Teece states 'while reputational capital is certainly not unique to professional service firms, it is frequently the most important asset. This is because other methods of selling - for instance, advertisingare usually quite ineffective” (Teece 2003: 902). Aharoni states that "the ability to give services globally is part and parcel of a perception of high reputation and an indicator of competence and commitment to service the customer. Global firms are able to transfer reputation from one geographical market to another. In fact, the major advantage of the giant global accounting, consulting or advertising firm is that clients believe these firms connote high quality' (Aharoni 2000: 127-8). Professional service firms rely especially on word of mouth recommendations or 'networked trust' (Gluckler and Armbruster, 2003) where reputation is gained and reinforced by connections to and endorsements from other powerful actors within particular corporate networks, e.g. around Wall Street and the City of London for law firms, around 'blue-chip' corporate clients for management consultancies etc.. Therefore professional service firms may see internationalisation as an opportunity to leverage their existing resources further by building and developing their existing reputation. 
The first way in which firms achieve this is often by following their clients abroad so that their initial contacts and networks can be leveraged further in new markets. This activity has been labelled as 'Client Following' and it may be accompanied by or lead onto Market Seeking strategies, i.e. looking for new clients in overseas markets. An alternative or complementary approach is to recruit or 'poach' senior consultants from other firms with existing client contacts in a particular region (see Pinault, 2001)

A rather more complex but equally important element concerns innovation. It is generally argued that innovation in professional service firms is an outcome of interaction with clients (rather than from the establishment of the equivalent of $R+D$ labs or the linkage with outside 'incubator' firms that characterizes some areas such as biotechnology and IT) (see e.g. Mills and Morris, 1986; Lowendahl et al. 2001). Clients’ problems generally have elements of novelty as well as routine. Professional service firms therefore tend to balance off the advantages of standardisation with those of the customisation of solutions depending on the sector of professional services in which they are working, their strategic positioning and their structural configuration. Extreme or, rather, explicit standardisation runs the risk firstly of a loss to reputation as clients feel 'cheated' and secondly that opportunities to identify new products and processes which can be sold on to other clients are missed. Professional service firms are likely, therefore, to look for ways in which new opportunities can be identified. Internationalisation in particular has the potential, as Bartlett and Ghoshal described in relation to manufacturing firms, to open up new innovative ways of doing things by diversifying the nature of the clients and the problems with which the firm deals. As Lowendahl states 'in PSFs, the competitive advantage, if achieved, results from the ability of the firm to continuously tap into the knowledge developed 
in all relevant centres of the world, regardless of the local market potential in these knowledge centres’ (Lowendahl 2000: 152).

These firm level drivers towards internationalisation have gradually got stronger as the broader environment has changed. Key elements here have been the emergence of forms of international standardization embedded in discourses of globalization. These revolve around arguments about the increasing integration of financial markets, the development of common global standards of business knowledge and techniques propounded in the media, business schools and management consultancies, and the emergence of formal and informal modes of international regulation (Morgan 2001a; 2001b; Thrift 1998). These discourses of globalization exert a powerful influence on many actors, providing for them both an understanding of the contemporary social and economic environment and also a way of acting in that environment. Large global professional services firms and their clients are key participants both in constructing this discourse and enacting it as a social reality in the face of potential national resistance (e.g. through spreading particular conceptions of law, e.g. Dezelay and Garth 1996; 2002a; 2002b; international standards of accounting, e.g. Arnold 2004; Botzem and Quack 2006 and particular forms of management knowledge e.g. SahlinAndersson and Engwall 2002). The global presence of professional service firms is legitimated by the discourse of open borders and common practices whilst the commonality of practices and discourses is reinforced by their actions for clients, both in the private sector and inside particular states or cross-national institutions such as the IMF, the World Bank and the WTO. 
In conclusion, there are a number of drivers towards the internationalisation of professional service firms. These can be partially explained in relation to previous models of internationalisation but for a variety of reasons, a number of other factors come into play. The issue of co-presence and the centrality of client-professional interaction is particularly important. This affects how firms internationalise in order to leverage their existing resources and build new products and innovations whilst maintaining and developing their global reputation. In the following section, we look at these issues particularly from the point of view of the management consultancy industry.

\section{The Management Consultancy industry and internationalisation}

In this section, we firstly concentrate on global management consultancy firms and how they organize themselves as 'transnationals'. In this respect our concern is with understanding the way in which they represent themselves as global and how this is seen to relate to their capabilities to serve clients. Secondly we look at this more critically and consider more specifically what 'being global' means in this context. We relate this to the broader problems of multinational organization described earlier as 'the subsidiary autonomy' debate, the 'governance' debate and the 'coordination costs' debate.

In organizational terms, global management consultancies vary in their strategy and structure (Kipping 2002). Two broad categories can be identified though there is some overlap between them. What Kipping refers to as the second wave consultancy groups (following the first wave originating out of the scientific management movement) are the prestigious ‘strategy’ consulting groups such as McKinsey and Boston Consulting 
Group. These firms became international in the 1950s and 1960s spreading their offices particularly into Europe as part of the broader expansion of US management ideas into the European environment that occurred at this time (Djelic 1998; McKenna et al. 2003). These firms were built on the partnership form of governance and have continued to retain this. Although their business interests have spread from pure 'strategy' research, they tend to remain distinctive in culture and approach from the other main grouping which emerged out of the big accounting firms in the 1980s (for an example of these differences in action see Empson 2001).

By size and geographical spread, the largest and most global management consultancies are those which originated inside accounting firms. In Kipping's terminology these are the third wave of consultancy business. The consultancy business of the accounting firms grew particularly on the basis of selling advice in the light of knowledge gained about management problems through the auditing process. This tended to be concerned with more operational issues than that of the strategy consultants, e.g. in terms of business processes and IT integration. More lately, the shift towards outsourcing of various functions, particularly associated with IT and various forms of payment, invoice and accounting procedures has added a third major leg to their business.

In organizational terms, the establishment of these businesses increasingly created tensions within the accounting firms. One aspect related to the relations between qualified accountants and the management consultants, issues which revolved around reward packages, prestige and status and generally power within the firm. Tension also emerged partly within the firm but also in the broader regulatory context 
concerning the impact of the drive for consulting income on the probity of auditing activities. In particular, it was increasingly claimed firms were being less objective about audits than was expected because they were keen to sell on consultancy services to their audit clients and did not wish to lose the potential for this more profitable business by being overly critical of the company on these issues (Stevens, 1981). The result has been the splitting off of consultancies from the accounting firms. The earliest example of this was when Accenture split off from the now deceased Arthur Andersen accounting company. More recently and more closely related to impact of regulatory scandals such as Enron, there has been increased pressure on the accounting firms to sell of their consulting arms. Cap Gemini bought Ernst \& Young's consulting arm in 1999 and in 2002 PwC Consulting was bought by IBM. KPMG's accounting arm was given a NASDAQ IPO in 2001 and following the acquisition of a number of ex-Andersen businesses changed its name to BearingPoint Inc in 2002. Interestingly, the separation of these units from their accounting firms meant a shift in governance, from the partnership structure to a shareholder structure and quotation on stock markets. Thus the two main areas of global consulting are now differentiated more strongly by their governance structure than by their broader strategic purposes.

What are the advantages which these global management consultancies bring to their tasks? Clearly this partly depends on the nature of the task, e.g. whether it predominantly requires work in one location or whether it spreads across national boundaries. Either way, however, the global management consultancy will claim advantages over local or national firms purely by virtue of its 'global reach' and the 
processes which are necessary to achieve this. As Backlund and Werr in their study of the websites of global consulting firms state;

“All firms underline that they are a global or international consulting firm. The global character of these companies is also reflected in their recurring descriptions of being 'world leaders' in their respective businesses. ...More or less implicit in these references to globality is the view that a global reach contributes to the consultancies' knowledge stock” (Backlund and Werr 2004).

The companies construct their global identity as key to their ability to serve their clients in a number of ways.

Firstly, in addition to general size advantages such as having potentially large numbers of staff available to work on large projects and as a back up if resource requirements change, there is the issue of experience and the global management consultancy firm's claim to have the experience of managing complex cross-national projects. It will claim benefit from what has been termed the 'economics of repetition', i.e. the existence of tried and tested processes inside the firm which enable it to pull together cross-national teams as a matter of routine. Secondly, the global firm will claim benefit from the stored expertise and knowledge of its consultants across the world who may have faced similar problems. Such firms have various techniques for capturing this knowledge ranging from 'knowledge management databases' which store cases and examples through to the identification of particular individuals as experts or centres of excellence (see below and Roberts, 2004) in the 
problem area, part of whose job is to resource the organization more generally with this knowledge as and when required (Rudolph and Okech 2003).

Overall the global management consultancy can claim to be advantaged by economies of scale (it has a greater source of specialised knowledge than comparable national firms), economies of scope (it has experience of a greater range of connected problems and solutions that can be leveraged by consultants to extend and develop the scope of activities), economies of repetition (it has an established set of routines that can be set into motion as and when projects are first mooted) and economies of learning (it has routines for capturing, managing and storing knowledge that can be used again).

On top of this the global management consultancy has the crucial advantage of reputation. In an area like consulting where there is no standardised knowledge base, reputation can be built through association and global consulting firms tend to be highly involved in this on a number of levels. One level concerns the process of recruitment itself. Global consultancy firms target the top business schools in the US for their junior recruits or subsequently send them to such schools. Armbruster, for example, states;

"The highly selective recruitment of outstanding individuals provided the consulting industry with a considerable touch of intellectual elitism....(and) is still considered a way of propagating the notion of an intellectual elite to the business environment...(Because) the quality of consulting services is difficult to determine...management consultancies need to signal the quality of their services by 
substitutive means, among which is a highly selective hiring process.” (Armbruster 2004: 1259).

Global management consultancies are keen to have long lists of applicants to enhance the elitism of those who are selected. Another way in which this is reinforced is through the almost exclusive reliance of the leading management consultancy firms on 'the case study interview - a job interview in which an abbreviated form of a Harvard Business School case study is posed to the candidate' (Armbruster 2004: 1250).

"Being a tool that is only used in management consulting, the case study serves as a signifier of otherness and analytical skills. Also...the selection procedure is associated with Harvard Business School and thus symbolizes special business training and competence’ (Armbruster 2004: 1260).

The fact that in most cases the selectors are themselves not trained HR practitioners but rather working consultants in the firm who 'have only received training in oneday or half-day courses' (op.cit.: 1258) reinforces the sense of an elite self-contained group. Alvesson and Karreman argue that this sort of recruitment policy and procedure contributes to 'producing a fairly homogeneous work force' (2004b: 431). In addition, strong cultural control in terms of selection, induction and training in corporate methods of analysis reinforces this effect (Roberts, 2004). This is even evident in cases where firms recruit from outside the firm, at more senior levels for example, where cultural fit is seen as important (Pinault, 2001) 
The management of reputation through recruitment and selection can be reinforced by formal links with business schools, such as supporting research or endowing chairs or sponsoring their staff onto MBA degrees. Management consultancies can also act 'like' universities and academics, e.g. by creating their own in-house learning institutes which draw in academics from universities or by encouraging their employers to present conference papers or publish in academic journals. They can also create their own publicly available journal along academic lines, e.g. McKinsey Quarterly. Consultancies can also draw reputation from the secondments which they support, e.g. into national or international governmental agencies as well as from the jobs which their consultants go on to after they leave the firm. In cases such as McKinsey, there are active efforts to sustain the McKinsey networks and publicise the connections that the firm has to important people and institutions. Reputation is also built through having the right sorts of firms as clients and having access to the right sorts of people within such firms and even recruiting from them or other consultancies with such client links.

Given all these advantages, how do these processes work out in practice? We look at this mainly from the point of view of how aspirations to share knowledge relate to other organizational processes in the firm. A useful case study which illuminates some key issues has been produced by Fenton and Pettigrew in their analysis of how Coopers and Lybrand (Europe) ${ }^{4}$ sought to develop their expertise in the area of pharmaceuticals by creating a cross-European network of expertise consisting of around 200 consultants. They state that 'in 1996 the pharma network was formally established as a business development group. It was required to develop an integrated

\footnotetext{
${ }^{4}$ Their study is based in the mid 1990s before Price Waterhouse and Coopers and Lybrand merged to form PWC and the Big Six became the Big Five.
} 
business plan across Europe'. In practice, however, a number of substantial barriers emerged to this network becoming an effective force within the firm. The first and most significant point was that the main power base in the firm was at the national level. This was strongly associated with the fact that the firm was in effect a federation of national partnerships. Individuals were members of particular national partnerships and it was at this level that careers and rewards were organized. Partners themselves, for example, were rewarded on the basis of the earnings which their national partnership achieved. Consulting projects were constructed at the national level even where they were with multinational firms. In all client engagements, there would be a lead partner and it would be the lead partner who would determine the membership of the team working on the project and how the division of labour was to be constructed. The purpose of the pharma network was to ensure that teams in this area were built from the best consultants no matter what their location. However, according to Fenton and Pettigrew, 'there was a strong perception that national firm requirements often took precedence over opportunities in the marketplace...the feeling was that they were still operating as a national organization rather than a European network' (Fenton and Pettigrew 2000: 100). Much of this was related to the fact that the ultimate profit centres and power centres in the firm were the national partnerships and within this, there were certain partnerships which were central and others which felt peripheral. For individuals it was most important to contribute to the profitability of the national firm and in this way earn high evaluations and promotion. For some firms, the pharma network was peripheral and their consultants were unlikely to become involved. For other firms, where senior partners were enthusiastic backers of the pharma network, consultants needed to be involved. In all these cases, the degree of knowledge sharing was contingent on other factors more deeply 
embedded at the national (i.e. organisational structural) level in terms of careers and rewards.

This is reinforced by deeper studies of how consultants are monitored and controlled. Alvesson and Karreman, for example, in two recent papers, refer to the 'technocratic' system of control in their management consulting case study (Alvesson and Karreman 2004a; 2004b). A number of their points reinforce our argument about the importance of local/national contexts. Firstly, they state that selection on to projects requires that juniors 'have good relationships with what they perceive as good project managers so that the latter will choose/offer them for projects that are attractive to work in' (Alvesson and Karreman 2004b: 432). Secondly, employees are evaluated on a frequent basis by their nearest boss, usually their project manager who grades them on performance. Thirdly they are provided with a mentor, usually a partner, who offers advice on career advancement. All of these processes are dominated by the local office, thus cutting across attempts to achieve cooperation across offices in different countries or regions 5 .

Much of this is associated with the inter-twined issues of careers and project budgeting in management consultancies. The evaluation and monitoring is part of a broader process of ensuring that new members of the firm see that their elite status on recruitment has to be sustained by high levels of commitment to the firm and effectiveness in fitting in with and contributing to the success of projects, especially in terms of generating repeat business or 'sell on'. The large consultancies therefore famously operate what are known as up or out promotion systems. In Nanda and

\footnotetext{
${ }^{5}$ Similar processes are described in the Harvard case study by Nanda and Morrell on consultants in Boston Consulting Group (Nanda and Morrell 2004).
} 
Morrell's study of BCG, they describe the expected timescale to move from associate to senior Vice President (the BCG partner level) as 10 years. Thus the anticipated period on each of the intermediary rungs of the ladder (consultant, project leader, manager) is around 2 to 3 years. An employee failing to be promoted in that time is basically counselled to leave the firm and given help in moving to another job, not least as they may become future clients. The outcome of this is that roughly one in ten of the new entrants is likely to reach partner level whilst the others will leave. For the individual this creates enormous pressures to perform, reflected in working long hours, a willingness to travel away from home and a general high level of commitment to the firm (see Alvesson 2000 for an analysis of the tensions involved in this process; also Alvesson 2001). It also creates a strong pressure to focus on relationships with particular key individuals who are likely to be based in one location, the local office. As one consultant told Nandy and Morrell in discussing whether to apply for a prestigious overseas relocation position (known as the Ambassador programme in BCG), 'by relocating for some time, I might be cutting myself out of the loop. How will I get back into a favourable position in the staffing pool? Will my next promotion be delayed?” (Nanda and Morrell 2004: 10). This reflects a broader problem in professional service firms concerning issues of relocation. In a context where relationships are crucial - with partners, with clients, with managers and consultants - movement out of a known environment to an office in another national partnership cuts the individual off from these sources of support and makes them vulnerable. For this reason, although these firms are characterised by high levels of mobility across national borders for purposes of doing projects with multinational firms, there is a general reluctance to make a more long-term move. This may be a possibility early in the career or as a carrot for a rather quicker 
promotion, especially if skills match those required by a prestige client, but at partner level it is less likely to be undertaken.

The argument here is not that the formal procedures of the firm discourage working on cross-national projects and sharing knowledge. In terms of the appraisals and evaluations which employees undergo, it seems clear that emphasis is given to these aspects of performance although this varies in practice. The issue is more to do with how the broader environment of career affects the individual in terms of (a) the willingness to share (where career advancement is in effect a tournament between peers) and (b) the amount of time which is available above and beyond project time to make this effective, not least given the difficulties of translating tacit into explicit knowledge. If lower level employees are involved in a tournament, what are the advantages of sharing knowledge particularly where time pressures are so tight? Of course, this may be built into an appraisal system but then it becomes difficult to disentangle the effects of the measures of sharing from the reality of sharing. Thus if sharing is measured, amongst other things, by the number of postings one makes to the knowledge management system then the tendency is to post more notices to the system whether or not they are useful. Such opportunistic behaviour can in theory be corrected by a further level of monitoring - how often is a posting used by others in the firm and how do they evaluate it? But all of this introduces new levels of complexity, bureaucracy and costs in order to correct what is a central part of the system, i.e. the tournament process and the effect it has on commitment and hours of work and thus on budgets, margins and profitability. 
This relates to the second point which is that of project budgeting and accounting for time. Alvesson and Karreman (2004b) describe the role of partners primarily in terms of selling projects and developing the client agreement. Their rewards (i.e. how many units - shares - they are allowed to purchase in the following year) are determined by the volumes of business sold and the margin achieved on that business. The issue of maximizing the margin and monitoring the budget is the responsibility of the project manager and this is done through planning the project in terms of manpower, resources and cost. This creates a strong framework within which the consultants' billable hours are strictly accounted for, leaving very little slack. On the contrary, as Alvesson and Karreman illustrate, billable hours often underestimate the actual hours undertaken by consultants, an issue that exercises the consultants greatly but is swept under the carpet by the project manager for the obvious reason that if all hours were accounted for, the price of the job would have to increase and the client might go elsewhere (Alvesson and Karreman 2004b; 433-436). In effect, partners rely on their ability to extract more hours from their juniors than they formally request; juniors conform, if reluctantly, because they know their reputation as a good team player (and therefore their promotion) is dependent on this.

Dunford links some of these issues to the effectiveness of formal knowledge management systems for sharing experiences. He states that the quality of information in such systems 'may be impaired at a very basic stage by consultants failing to feed information into their firm's system, This may be due to something as fundamental as time pressure' (Dunford 2000: 297) He also points to the way in which performance evaluations primarily based on billable hours 'discouraged consultants from taking 
time to package and share new insights' (op.cit.: 298). His overall conclusion is that 'a lot of the investment in knowledge management is an act of faith' (op.cit. 301).

This relates to a broader point about the nature of the global management firms. Their basic organizational unit is the national partnership and the local offices within that framework. This is where rewards and careers at all levels are ultimately determined. It is where business is generated and projects managed. Where national partnerships gain most clearly from their membership of a global firm is in reputational terms. In practical terms of sharing information, knowledge and practice across boundaries the gains are more limited although there is some benefit from drawing on (functional/client) specialists, albeit at a distance, by phone, email and video for example. Clearly many consultancies share a standard model of work practices and they also share a general registry of expertise and knowledge. However, to make this more than a limited benefit requires efforts at integration, cooperation and joint learning that have one obvious drawback as far as all members of the firm are concerned. That drawback is that they generate high overheads. For example, establishing an in-house university or an international management development is very expensive and involves taking consultants off billable activity. Establishing a global network of expertise that can be called upon at any point to advise on projects is expensive if it extends beyond a list of names and telephone numbers. Capturing more of the firm's revenue to support activities which are not directly revenue creating goes against the grain of these highly focused, budget driven organizations as well as against the interests of most of the individuals inside them. Thus firms can espouse the rhetoric of global knowledge management systems and global integration of teams and knowledge, but in reality they find it very difficult to deliver this except 
insofar as their services are standardised. The firms with the highest margins on business (i.e. the strategy firms) are likely to be better able to move in this direction than the mass consultancy firms which tend to focus on lower margin projects. However, contrary to their projected image, even the strategy houses offer standardised forms of analysis so whatever the type of the firm, the problems are large. As Fenton and Pettigrew state 'our probing within the Professional service organizations revealed a discernible system-wide imbalance in the degree of integration within their networks because of a variety of confounding factors' (Fenton and Pettigrew 2003: 230). These confounding factors include contextual issues (differences across national markets, skill differences between partners), historical factors (concerned with how different national groups saw the historical inequalities between partnerships) and social factors. On social factors they state;

"None of the PSOs had developed effective sanctions beyond peer group pressure; similarly there was little in the way of reward and recognition systems in place to encourage positive behaviour in the changed firms.” (Fenton and Pettigrew 2003: 232).

In addition, it is important to note the role of clients in shaping consulting practices, especially the more sophisticated, innovative or active ones who may well resist the offer of a standard consulting approach (Sturdy, 1997).

In conclusion, then, our argument is that just as with global multinational firms in the manufacturing area there are good reasons for believing that there are inherent limitations to the growth of global firms in management consultancy. To return to our three debates in MNCs on subsidiary autonomy, governance of the global entity and 
coordination costs, we conclude as follows. Firstly, 'subsidiaries' tend to have high levels of autonomy. Indeed, up until recently the global management consultancies were run as federations of national partnerships ${ }^{6}$. It is at the national level that business is won and the main rewards are distributed. 'Global' controls on the national context vary in terms of their intensity and effectiveness. Standard methodologies in particular areas and shared databases of expertise may be one useful element but most crucial at the global level is the reputational element. Local offices need to sustain this reputation and although this creates some constraints, there are many areas of freedom that remain. Thus we conclude that global management consultancies have relatively high levels of subsidiary autonomy, e.g. to develop new business areas, new techniques etc. ${ }^{7}$ In terms of governance, our general conclusion is that 'global governance' in such firms is weak and as a result there may frequently arise tensions between different national practices in terms of how far 'peripheral' practices become involved in the large projects won in the big consulting markets. The issue of how far work is contracted out from a lead partner in one country to consultants in other countries is unclear. Barrett et al.'s (2005) recent analysis of how international audits are coordinated across different national practices within the same global firm reveals that this can involve complex political and economic bargaining between more or less powerful national partnerships (for similar arguments see also Rose and Hinings 1999 which looks at Global Business Advisory firms which they label GBAFs, i.e. accounting firms with consultancy arms). Overall, therefore, the potential for political action within the global structure of the firm seems high, though this may be mitigated by two factors. Firstly in most of the global consultancies, the US partnership is dominant by virtue of the strength of the US consulting markets and

\footnotetext{
${ }^{6}$ It will be interesting to see how the shift to plc status for those companies spun off from the accounting firms may impact on these issues in the future.

${ }^{7}$ For similar arguments developed from a rather different perspective see Jones 2002; 2003)
} 
the central role of the US partnership in sustaining reputation and cultural control. Secondly, the relatively limited resources placed at the global level means that there is not so much worth fighting for as there is in manufacturing firms where the global headquarters effectively controls the surplus as well as access to investment funds through the capital markets ${ }^{8}$. Finally, the issue of coordination costs across national boundaries impacts on two levels. Firstly, it is a considerable problem at the level of projects and creating integrated learning. The tight budgetary control exercised on activities through the billable hours system militates against expenditure on crossnational coordination. Secondly, the structure of national partnership control means that the global level is relatively weak and dependent for resources. It can therefore only achieve limited objectives in terms of 'global activities'. Thus coordination costs are kept relatively low in these systems but the result is that the global integration which is proclaimed as an essential part of their competitive advantage is not actually achieved.

\section{Discussion and conclusion}

Our analysis of the global management consultancy firm suggests that there are organizational problems which mean that it is does not deliver on the 'transnational solution' as described by Bartlett and Ghoshal. Where it delivers is in terms of reputation and as Aharoni (2000) and others have pointed out this is essential not least because in the arena of professional services, there are high levels of uncertainty and ambiguity concerning the effectiveness of consultancy interventions (Sturdy 1997; also Clark and Fincham 2002). Reputation works for both clients and consultants. For clients it gives them some security in their decisions and the effectiveness of those

\footnotetext{
${ }^{8}$ Rose and Hinings provide an interesting discussion of the international level of governance in their analysis of GBAFs.
} 
decisions even where this is difficult to measure. For consultants, it imbues them with a sense of being members of an elite with access to privileged and specialist knowledge and confidence in its application. Managing reputation on a global scale works for national partnerships as well, enabling them relative autonomy so long as they stick to the essential elements that make up the reputation, i.e. the recruitment procedures, the up or out promotion system, the maintenance of prestigious client lists etc.

On the other hand, if the outcome of this is that the nature of what is delivered is not distinctively 'transnational', it opens up the question of whether other forms of management consultancy organization might not still be able to grow and prosper in particular areas of the market. Kipping et al's recent paper reinforces this point in that they note that 'the consultancy fields in most European countries continue to be dominated by individual or very small service providers of domestic origins.' (Kipping et al. 2003: 37; see Rudolph and Okech 2004 for the German case). The nature of national management consultancy markets is clearly different and continues to affect both the sort of consultancy services required and more particularly the nature of the clients, the firms and public organizations requiring those services (see the interesting collection of papers in Kipping and Engwall 2002 which look at different national contexts). Lowendahl, for example, distinguishes between global clients, local clients with 'global problems' and local clients with local 'problems' (Lowendahl 2000:153-157). Whilst one would obviously expect a dominance of global management consultancies with global clients and the dominance of local consultancies over local clients, there is an area in the middle where there may be a great deal of competition. Partly this is an issue of size in that global firms are also 
typically large firms and can reduce the risk to clients by having a relatively flexible resource base in terms of the number and skills of available consultants, but there are also cost implications. Global management consultancy firms incur large costs in their recruitment and career management. They are unlikely to be able to compete on cost terms with more local or national firms so clients will have to balance out these cost considerations with reputational and competence considerations before deciding how to allocate business. Partly this is also an issue of the relationship to clients and how well being part of a global management consultancy may facilitate that. For example, one of the ways in which 'national' firms emerge is through consultants moving out of the global business to set up their own firm. Their international experience is clearly beneficial in this but their independence from the global firm and their potential network derived both from the global firm and their broader social, political and educational contacts may be relevant to them winning clients against the global firm. This independence often enabled them to adapt the dominant American message and the American techniques of the global firm even more closely to the local circumstances. Local high status employees could use their own high status and that of the firm which they had just left to make their way into local networks. There is evidence that one issue for these types of firms is that they begin to imitate too strongly their US origins leading them into expansion plans which eventually end up with them seeking out a merger with one of the global firms or being sought out on the basis of (re-)capturing their client base. Such high profile national firms have therefore tended to decline in significance over the last decade particularly as they have found that their home based MNC clients are more interested in international advice provided by high status international management consultancies with greater resources. Therefore the space for this sort of firm has been severely squeezed. 
On the other hand there is clearly the continued existence of a sub-strata of local firms with smaller scale but higher specialization that can seek to service national clients. It is this grouping which is least researched. There is a tendency to assume that this grouping basically serves small and medium sized firms rather than multinationals and therefore is not really of interest to debates on internationalisation. However, in our view, this case is not proven. There are some indications in management consultancy (as there are in law) that highly specialist, small-scale 'boutique' operations can gain business in large multinationals in particular areas. Such consultancies can legitimate the claim to customisation and 'unique solutions' in a way which the global firms cannot so easily do. While they lack the flexibility derived from scale advantages, they can keep overheads relatively low and ensure that their seniors work more directly with the clients throughout the process. What is less clear is whether such firms can at least in part leverage their own international capabilities by entering into networks. Historically, a lot of cross-border trade ${ }^{9}$ in professional services has been conducted through networks of referrals and limited movements of high reputation individuals. In this model, clients of professional services firm A in country $\mathrm{Z}$ requires advice about its activities in country Y. Firm A is in a network with other independent firms including firm B in country Y. The client's problem is referred to firm B by firm A. In many networks, there will be no fee for the referral as the network works on the basis of long-term reciprocity so that firm A will expect in the future to receive a referral from firm B. Firm B bills the client directly. Such networks can take many forms in terms of formality, virtuality, permanence, mechanisms of control and governance. However, they are unlikely to appear in FDI

\footnotetext{
${ }^{9}$ Such referral networks are also relevant within societies, particularly where regulations have constrained a firm from establishing multiple offices across different localities (as has been the case for law firms in many countries) but also in conditions of geographical distance.
} 
statistics (because there is no flow of capital, just information) even though they may well be the most common way in which small and medium sized firms are able to seek advice on international issues. The idea of referral networks in management consultancy is relatively unexplored. Clearly the management of such networks would need to be very careful as alliances with the 'wrong sort' of partners could destroy credibility. On the other hand in the right circumstances it might be a possible alternative to the global firm though there is little research on this issue yet which can provide detailed information on which to make a judgement. The network may provide a way for smaller more specialist firms to serve international clients as well as smaller firms with international requirements. Another aspect of this relates to the 'virtual firm'. There are a number of examples of nationally based consultancy operations which are, in effect, 'virtual firms'. By this we mean that the firm itself is simply an administrative centre; it does not have its own compliment of consultants but rather has a list of other firms (often very small operations down to one person businesses) on whom it can call when an enquiry is made. In effect it acts as a dating agency bringing together the client and the consultant. However, the client may be unaware that this is what happens and may believe that the consultant is an employee of the firm with which the initial contact was made. The 'virtual firm' model may appear highly precarious as it is unclear how standards of service are monitored and protected although the professional consulting associations are more evident at the level of small and medium sized firms. On the other hand it reduces overhead costs significantly and has the potential for reaching beyond the national context.

In conclusion, our argument is that the internationalisation of management consultancy firms should not be studied solely form the perspective of the global 
firms. If we look in more detail at these firms we can see that the benefits which they get form internationalisation are primarily derived from reputation. Underneath this the global firms remain federations of national partnerships with limited integration or knowledge sharing. In particular national markets, national firms are likely to be able to link more carefully to the distinctive characteristics of those contexts, most obviously in terms of their relations with small and medium sized enterprises but also in other ways through their ability to adapt broader messages and techniques to local contexts. Furthermore, national firms are not necessarily confined within national markets. The possibility of network connections or of the creation of virtual firms linking independent consultants to a common marketing arm also exists. It will be an interesting project for future research to examine more carefully the extent and significance of such alternative international forms.

\section{Reference List}

Aharoni, Y. (2000) The role of reputation in global professional business services. In: Aharoni, Y. and Nachum, L., (Eds.) Globalization of Services, pp. 125-141. London: Routledge

Aharoni, Y. and Nachum, L. (2000) Globalization of Services, London: Routledge.

Alvesson, M. (2000) Social Identity and the Problem of Loyalty in KnowledgeIntensive Companies Journal of Management Studies 37,8, pp.1101-1123)

Alvesson, M. (2001) Knowledge work: ambiguity, image and identity. Human Relations 54, 863-886.

Alvesson, M. and Karreman, D. (2004a) Cages in Tandem: Management control, social identity and identification in a knowledge-intensive firm. Organization 11, 149-175.

Alvesson, M. and Karreman, D. (2004b) Interfaces of control. Technocratic and socio-ideological control in a global management consultancy firm. Accounting, Organizations and Society 29, 423-444.

Armbruster, T. (2004) Rationality and its symbols: signalling effects and subjectification in management consulting. Journal of Management Studies 41, 1247-1269. 
Arnold, P. (2004) Disciplining domestic regulation: the World Trade Organization and the market for professional services Accounting, Organizations and Society 30, 299-330.

Backlund, J. and Werr, A. (2004) The construction of global management consulting a study of consultancies' web presentations. In: Buono, A.F., (Ed.) Creative Consulting: Innovative Perspectives on Management Consulting, Greenwich,CT: Information Age Publishing

Barrett, M., Cooper, D. and Jamal, K. (2005) Globalization and the coordinating of work in multinational audits. Accounting, Organizations and Society 30, 124.

Bartlett, C. A., and Ghoshal, S. (1989). Managing across Borders: The Transnational Solution. London: Century Business.

Beaverstock, J. (2004) 'Managing across Borders': knowledge management and expatriation in professional service legal firms Journal of Economic Geography 4, pp.157-179.

Beaverstock, J., Smith, R.G., Taylor, P. (2000) Geographies of Globalization: US Law Firms in World Cities Urban Geography, 21, 2, pp.95-120.

Beaverstock, J., Smith, R.G., Taylor, P. (1999) The Long Arm of the Law: London's Law Firms in a Globalizing World Economy Environment and Planning A, 31, 10, pp.1857-1876.

Belanger, J., Berggren, C., Bjorkman, T., and Kohler, C. (1999). Being Local and Worldwide: $A B B$ and the Challenge of Global Management. Ithaca, NY: ILR imprint, Cornell University Press.

Birkinshaw, J. (1997). 'Entrepreneurship in Multinational Corporations: The Characteristics of Subsidiary Initiatives’. Strategic Management Journal, 18: 207-29.

— (2000). Entrepreneurship in the Global Firm. London: Sage.

- (2001). 'Strategy and Management in MNE Subsidiaries', in A. Rugman and T. L. Brewer (eds.), The Oxford Handbook of International Business. Oxford: Oxford University Press.

Botzem, S. and Quack, S. (forthcoming) 'Contested Rules and Shifting Boundaries: International Standard Setting in Accounting', in Djelic, M.-L. and SahlinAndersson, K. (eds.), Transnational regulations in the making. Cambridge: Cambridge University Press.

Brock.D., Powell, M. and Hinings, C.R. (1999) Restructuring the professional organization, London: Routledge.

Bryson, J.R., Daniels, P.W. and Warf, B. (2004) Service Worlds: People, Organisations, Technologies, London: Routledge. 
Castells, M. (1996) The rise of the network society, Oxford: Blackwells.

Clark, T. and Fincham, R. (2002) Critical Consulting: New Perspectives on the Management Advice Industry, Oxford: Blackwell.

Clark, T. (1995) Managing Consultants, Buckingham: Open University Press.

Dezelay, Y. and Garth, B.(1996) Dealing in Virtue Chicago; University of Chicago Press.

Dezelay, Y. and Garth, B. (2002a). The Internationalization of Palace Wars. Chicago: University of Chicago Press.

Dezelay, Y. and Garth, B. (eds.) (2002b). Global Prescriptions. Ann Arbor: University of Michigan Press.

Djelic, M-L. (1998). Exporting the American Model. Oxford: Oxford University Press.

Dunford, R. (2000) Key challenges in the search for the effective management of knowledge in management consulting firms. Journal of Knowledge Management 4, 295-302.

Dunning, J. (1993) The Globalization of Business, London: Routledge.

Dunning, J. (1993) The globalization of service activities. In: Dunning, J., Globalization of Business, pp. 242-284. London: Routledge

Empson, L. (2001) Fear of exploitation and fear of contamination: impediments to knowledge transfer in mergers between professional service firms. Human Relations 54, 839-862.

Fenton, E.M. and Pettigrew, A.M. (2003) Complementary change: towards global integration in four professional service organizations. In: Pettigrew, A.M., Whittington, R., Melin, L., Sanchez-Runde.C., van den Bosch, F., Ruoigok, W. and Numagami, T., (Eds.) Innovative forms of organizing, pp. 208-239. London: Sage

Fenton, E.M. and Pettigrew, A.M. (2000) The role of scoial mechanisms in an emerging network: the case of the pharmaceutical network in Coopers \& Lybrand Europe. In: Pettigrew, A.M. and Fenton, E.M., (Eds.) The innovating organization, pp. 82-116. London: Sage.

Geppert,M., Matten,D. Williams, K. (2003) Challenges for European Management in a Global Context London: Palgrave Macmillan

Giddens,A. (1990) The Consequences of Modernity Cambridge: Polity Press.

Gluckler, J and Armbruster, T (2003) 'Bridging Uncertainty in Management Consulting - The Mechanisms of Trust and Networked Reputation', Organization Studies, 24, 2, 269-297. 
Hedlund, G. (1986). ‘The Hypermodern MNC—A Heterarchy?’ Human Resource Management, 25: 9-35.

(1993). 'Assumptions of Hierarchy and Heterarchy: An Application to the Multinational Corporation', in S. Ghoshal and D. E. Westney (eds.),

Organization Theory and the Multinational Corporation. London: Macmillan.

— (1999). 'The Intensity and Extensity of Knowledge and the Multinational Corporation as a Nearly Recomposable System' Management International Review 1999,1, pp.5-44.

Henry, O. (2002) The acquisition of symbolic capital by consultants: the French case. In: Kipping, M. and Engwall, L., (Eds.) Management consulting: emergence and dynamics of a knowledge industry, pp. 19-35. Oxford: Oxford University Press

Jones, A. (2002) The 'global city' misconceived: the myth of 'global management' in transnational service firms. Geoforum 33, 335-350.

Jones, A. (2003) Management Consultancy and Banking in an era of Globalization, edn. London: Palgrave Macmillan.

Kipping, M. (2002) Trapped in their Wave: the evolution of management consultancies. In: Clark, T. and Fincham, R., (Eds.) Critical Consulting: New Perspectives on the Management Advice Industry, pp. 28-49. Oxford: Blackwell

Kipping, M. and Engwall, L. (2002) Management consulting: emergence and dynamics of a knowledge industry, Oxford: Oxford University Press.

Kipping, M., Furusten, S. and Gammelsaeter, H. (2003) Converging towards American dominance? Developments and Structures of Consultancy Fields in Europe. Enterprises et Histoire 33, 25-40.

Kristensen, P.H. and Zeitlin, J. (2005) Local Players in Global Games Oxford: Oxford University Press.

Lamoreaux, N.R., Raff, D.M.G. and Temin, P. (2002) Beyond Markets and hierarchies: Toward a new synthesis of American Business History. NBER Working Paper Series working paper 9029,

Langlois, R.N. (2003) The vanishing hand: the changing dynamics of industrial capitalism. Industrial and Corporate Change 12, 351-385.

Lowendahl, B., Revang,O.,Fosstenlokken,S. (2001) Knowledge and Value Creation in professionals Service firms: a framework for analysis Human Relations 54,7,pp.911-931.

Lowendahl, B.R. (2000) The globalization of professional business service firms: Fads or genuine source of competitive advantage. In: Aharoni, Y. and Nachum, L., (Eds.) Globalization of Services, pp. 142-162. London: Routledge 
McKenna, C., Djelic, M.-L. and Ainamo, A.(2003) 'Message and medium: the role of consulting firms in globalization and its local interpretation', in Djelic, M.-L. and Quack, S. (eds.), Globalization and Institutions. Edward Elgar, 83-107.

Mills, P K and Morris, M (1986) 'Clients as Partial Employees of Service Organizations: Role Development in Client Participation', Academy of Management Review, 11, 4, 726-735

Morgan,G., Whitley,R. and Moen, E. (2005) Changing Capitalisms? Internationalisation, Institutional Change and systems of economic organization Oxford: Oxford University Press.

Morgan, G. and Quack,S. (2005) Internationalization and Capability Development in Professional Services Firms in Morgan,G. Whitley,R. and Moen, E. (2005) Changing Capitalisms? Internationalisation, Institutional Change and systems of economic organization pp. 277-311 Oxford: Oxford University Press.

Morgan, G. (2005) Understanding Multinational Corporations in Ackroyd,S., Arnold, P., Batt,R. and Thompson,P. The Oxford Handbook of Work and Organizations, pp. 554-576 Oxford: Oxford University Press

Morgan, G. and Quack, S. (2004) Institutional legacies and firm dynamics: the internationalization of British and German Law firms' (Mimeo)

Morgan, G. (2001a). Transnational Communities and Business Systems, Global Networks 1(2):113-130

Morgan, G. (2001b).The development of Transnational Standards and Regulations and their Impacts on Firms, in Morgan, G., Kristensen, P.H. and Whitley, R. eds. The Multinational Firm: Organizing Across National and Institutional Divides pp.225-252 Oxford: Oxford University

Morgan, G., Kristensen, P.H. and Whitley, R. eds. (2001) The Multinational Firm: Organizing Across National and Institutional Divides Oxford: Oxford University.

Nachum, L. (2000) FDI, the location advantages of countries and the competitiveness of TNCs: US FDI in professional service industries. In: Aharoni, Y. and Nachum, L., (Eds.) Globalization of Services, pp. 75-92. London: Routledge

Nanda,A. and Morrell,K. (2004) Developing Professionals - The BCG Way (A) Harvard Business School Case 9-903-113

Nohria, N., and Ghoshal, N. (1997). The Differentiated Network: Organizing Multinational Corporations for Value Creation. New York: Jossey-Bass.

Pinault, L (2001) Consulting Demons - Inside the Unscrupulous World of Global Corporate Consulting, New York: Harper Business.

Roberts, J. (2004) Global management consultancy: conceptual issues concerning the 
cross-border delivery of knowledge intensive services (paper presented at the British Academy of Management, Sept. 2004)

Roberts, J. (1999) The internationalisation of business service firms: a stages approach. Service Industries Journal 19, 68-88.

Roberts, J. (1998) The Internationalisation of Business Service Firms, Aldershot: Ashgate.

Rose, T. and Hinings, C.R. (1999) Global Clients' demands driving change in global business advisory firms. In: Brock.D., Powell, M. and Hinings, C.R., (Eds.) Restructuring the professional organization, pp. 41-67. London: Routledge.

Rudolph, H. and Okech, J. (2003) 'Computer, Köpfe, Communities of Practice. Internationales Wissensmanagement in großen Unternehmensberatungen', in Dörrenbächer, C. (ed.) Modelltransfer in Multinationalen Unternehmen. Edition sigma, Berlin, 29-52.

Rudolph, H. and Okech, J. (2004) Wer anderen einen Rat erteilt ... Wettbewerbsstrategien und Personalpolitiken von Unternehmensberatungen in Deutschland. Edition sigma, Berlin.

Sahlin-Andersson, K. and Engwall,L. (2003) The Expansion of Management Knowledge: Carriers, Flows and Sources Stanford: Stanford University Press

Sassen,S. (2001) The Global City revised ed. Princeton, NJ: Princeton University Press.

Solvell, O., and Zander, I. (1998). 'International Diffusion of Knowledge: Isolating Mechanisms and the Role of the MNE', in A. D. Chandler, O. Solvell, and P. Hagstrom (eds.), The Dynamic Firm: The Role of Technology, Strategy, Organization and Regions. Oxford: Oxford University Press.

Solvell, O. (2003) 'The Multi-home based Multinational: Combining Global Competitiveness and Local Innovativeness’ in Birkinshaw, J., Ghoshal,S., Markides,C., Stopford,J., Yip,G. (2003) The Future of the Multinational Company pp.34-44 London: Wiley.

Spar,D. (1997) Lawyers Abroad: the internationalisation of legal practices California Management Review 39, pp.8-28.

Stevens, M (1981) The Big Eight, New York: Collier

Sturdy, A. (1997) The consultancy process - an insecure business. Journal of Management Studies 34, 389-413.

Sturgeon, T.J. (2002) Modular production networks: a new American model of industrial organization. Industrial and Corporate Change 11, 451-496.

Taylor,P.J. (2004) World City Network London: Routledge.

Teece, D. (2003) Expert talent and the design of (professional services) firms. 
Industrial and Corporate Change 12, 895-916.

Thrift, N. (1998) Virtual capitalism: the globalisation of reflexive business knowledge. In: Carrier, J.G. and Miller, D., (Eds.) Virtualism: a new political economy, pp. 161-186. Oxford: Berg

UNCTAD (2004) World Investment Report 2004 Geneva: UNCTAD.

Warf,B. (1997) Global Dimensions of US Legal Services The Professional Geographer, 53,3, pp.398-406.

Werr, A. (2002) The internal creation of consulting knowledge: a question of structuring experience. In: Kipping, M. and Engwall, L., (Eds.) Management consulting: emergence and dynamics of a knowledge industry, pp. 91-108. Oxford: Oxford University Press

Werr, A. and T.Stjrenberg (2003) Exploring management consulting firms as knowledge systems. Organization Studies 24,6 pp. 881-908.

Whitley,R. (2005) Developing Transnational Organizational Capabilities in Multinational Companies: Institutional Constraints on Authority Sharing and Careers in Six Types of MNC in Morgan,G. Whitley,R. and Moen, E. (2005) Changing Capitalisms? Internationalisation, Institutional Change and systems of economic organization pp. 235-276 Oxford: Oxford University Press. 


\section{$\underline{\text { CSGR Working Paper Series }}$}

145//04, October

146/04, October

147/04, October

148/04, October

149/04, October

150/04, October

151/04, November

152/04, October

153/04, November

154/04, November

155/05 December

156/05, January

157/05, February

158/05, February

159/05, March

160/05, May
J Whalley

Rationality, Irrationality and Economic Cognition

M Redoano

Does Centralization Affect the Number and Size of Lobbies?

M P Devereaux, B Lockwood and M Redoano

Horizontal and Vertical Indirect Tax Competition: Theory and Some Evidence from the USA

M Besfamille \& B Lockwood

Are Hard Budget Constraints for Sub-National Governments Always Efficient?

P S Martins

Do Foreign Firms Really Pay Higher Wages? Evidence from Different Estimators

R Icaza

Civil Society in Mexico and RegionalisationA Framework for Analysis on Transborder Civic Activism

G Grimalda

A Game-Theoretic Framework to Study the Influence of Globalisation on Social Norms of Co-operation

M Caselli

Some Reflections on Globalization, Development and the Less Developed Countries

D Leech \& R Leech

Voting Power and Voting Blocs

D Leech \& R Leech

Voting Power in the Bretton Woods Institutions

B Lockwood \& M Redoano

The CGSR Globalisation Index Website

D Leech \& R Leech

Voting Power implications of a Unified European Representation at the IMF

H Nesadurai

Conceptualising Economic Security in an Era of Globalisation: What Does the East Asian Experience Reveal?

S Sullivan

'Viva Nihilism!' On militancy and machismo in (anti-)globalisation protest

S Ghosal and K Thampanishvong

Sovereign Debt Crisis: Coordination, Bargaining and Moral Hazard

R Cohen

The free movement of money and people: debates before and after ' $9 / 11$ ' 


\begin{tabular}{|c|c|}
\hline 161/05, May & $\begin{array}{l}\text { E Tsingou } \\
\text { Global governance and transnational financial crime: opportunities and } \\
\text { tensions in the global anti-money laundering regime }\end{array}$ \\
\hline 162/05, May & $\begin{array}{l}\text { S. Zahed } \\
\text { 'Iranian National Identity in the Context of Globalization: dialogue or } \\
\text { resistance?' }\end{array}$ \\
\hline 163/05, May & $\begin{array}{l}\text { E. Bielsa } \\
\text { 'Globalisation as Translation: An Approximation to the Key but Invisible } \\
\text { Role of Translation in Globalisation’ }\end{array}$ \\
\hline 164/05, May & $\begin{array}{l}\text { J. Faundez } \\
\text { 'The rule of law enterprise - towards a dialogue between practitioners and } \\
\text { academics' }\end{array}$ \\
\hline 165/05, May & $\begin{array}{l}\text { M. Perkmann } \\
\text { 'The construction of new scales: a framework and case study of the } \\
\text { EUREGIO cross-border region' }\end{array}$ \\
\hline 166/05, May & $\begin{array}{l}\text { M. Perkmann } \\
\text { 'Cross-border co-operation as policy entrepreneurship: explaining the } \\
\text { variable success of European cross-border regions' }\end{array}$ \\
\hline 167/05, May & $\begin{array}{l}\text { G. Morgan } \\
\text { 'Transnational Actors, Transnational Institutions, Transnational spaces: The } \\
\text { role of law firms in the internationalisation of competition regulation' }\end{array}$ \\
\hline 168/05, May & $\begin{array}{l}\text { G. Morgan, A. Sturdy and S. Quack } \\
\text { 'The Globalization of Management Consultancy Firms: Constraints and } \\
\text { Limitations' }\end{array}$ \\
\hline
\end{tabular}
Limitations'

\section{Centre for the Study of Globalisation and Regionalisation}

University of Warwick

Coventry CV4 7AL, UK

Tel: +44 (0)24 76572533

Fax: +44 (0)24 76572548

Email: csgr@warwick.ac.uk

Web address: http://www.csgr.org 